\title{
Constraints Faced By Farmers in Agriculture Living In Peri-Urban Area of Nagpur
}

\author{
Vrushali M. Yadav ${ }^{1}$, Santosh S. Shende ${ }^{2 *}$ and V. S. Tekale ${ }^{1}$ \\ ${ }^{1}$ Extension Education Section, College of Agriculture, Nagpur, India \\ ${ }^{2}$ Extension Education Section, College of Agriculture, Parbhani, India \\ *Corresponding author
}

\section{A B S T R A C T}

The present study was conducted in Nagpur district of Vidarbha region, Maharashtra State. The sample consisted of 100 farmers from peri-urban area of Nagpur. The data regarding the effect of urbanization on agriculture were

Keywords

Urbanization, Periurban area

Article Info

Accepted:

18 July 2019

Available Online:

10 August 2019 collected using pre-tested interview schedule. A study was undertaken on different effect aspect i.e. crop cultivation, livestock, agriculture market, subsidiary occupation, farmers and others. It was observed that 89.00 per cent of farmers from peri-urban area faced major constraints was construction of buildings on agricultural land by private constructors, while 86.00 per cent farmers faced scarcity of labour due to migration to urban areas, whereas 85.00 per cent faced high labour wages, while 83.00 per cent farmers had unwillingness towards agriculture. 82.00 per cent farmers reported they didn't get proper information to climate change. The major constraint faced by farmers from peri-urban area were construction of buildings on agricultural land by private constructors which results in to conversion of agricultural land in to non-agricultural lands, scarcity of labour, high labour wages, unwillingness of farmers towards agriculture and not getting proper information.

\section{Introduction}

Urbanization is an index of transformation from traditional rural economies to modern industrial one. It is a progressive concentration of population in urban unit (Davis, 1965).

Kingsley Davis has explained urbanization as process of switch from spread-out pattern of human settlements to one of concentration in urban centers. It is a finite process-a cycle through which a nation passes as they evolved from agrarian to industrial society (Davis and Golden, 1954).

In the present context of rapid urbanization, several experts have suggested the need for encouraging peri-urban agriculture for ensuring food and nutritional security and helping farmers in these areas to retain their traditional livelihood. Peri-urban areas have been called 'no-man's land' as they lie outside 
the jurisdiction of urban local bodies and the surrounding rural areas lack resources to provide adequate amenities. (Khurana, 2010). But peri-urban agriculture faces threats like encroachment for urbanization, use of contaminated water for irrigation and the high rate of pesticide application. So, peri-urban agriculture should be supplemented by good agricultural practice and integrated pest management. In the last two decades, increasing urbanization along with exponential growth in population has led to contraction of cultivable farm areas and migration of rural population to urban areas in search of jobs. This increase in population has raised the problems of food and nutrition security. Although India has met the food security needs, it is yet to gain nutritional efficiency.

FAO provides support to peri-urban agriculture as part of its national food security programme and also to attain the millennium goal of poverty eradication.

To study Constraints faced by farmers in periurban area of Nagpur

\section{Materials and Methods}

The present study was conducted in Nagpur district of Vidarbha region in Maharashtra State with the help of ex-post-facto research design of social research. The data was collected from peri-urban area of Nagpur district, where maximum area under agriculture.

The lists of farmers were obtained from tehsil agriculture department of Nagpur. The data were collected personally by the researcher with the help of structured interview schedule developed for this purpose. The farmer respondents were contacted at their home or their farm. Total 100 farmers' respondents were interviewed and their responses were recorded in the schedule.

\section{Results and Discussion}

Constraints faced by the respondent living in peri-urban area

To identify the constraints faced by the farmers in agriculture in peri-urban area was one of the objectives of the present study.

The constraints are the circumstances or cause which prohibit or restraint the farmer's in periurban area.

It was observed from Table that, 89.00 per cent of farmers from peri-urban area faced major constraints was construction of buildings on agricultural land by private constructors, while 86.00 per cent farmers faced scarcity of labour due to migration to urban areas, whereas 85.00 per cent faced high labour wages, while 83.00 per cent farmers had unwillingness towards agriculture. 82.00 per cent farmers reported they didn't get proper information to climate change.

Other constraints experienced by peri-urban farmers were no trained youth due to migration to urban area for education or employment was 81.00 per cent, high cost of organic inputs 79.00 per cent, weather uncertainty 78.00 per cent, non-availability of compost 75.00 per cent and high price of seed, fertilizer, and chemicals 63.00 per cent. 63.00 per cent farmers faced non-availability of credit facilities in time, lack of technical assistance 56.00 per cent and lack of technical information 40.00 per cent.

The major constraint faced by farmers from peri-urban area were construction of buildings on agricultural land by private constructors which results in to conversion of agricultural land in to non-agricultural lands, scarcity of labour, high labour wages, unwillingness of farmers towards agriculture and not getting proper information. 
Table.1 Distribution of respondents according to constraints faced by them in agriculture in periurban area

\begin{tabular}{|c|l|c|c|}
\hline $\begin{array}{c}\text { Sr. } \\
\text { No. }\end{array}$ & \multicolumn{1}{|c|}{ Constraints } & $\begin{array}{c}\text { Respondents } \\
(\mathbf{n = 1 0 0}) \\
\text { Frequency }(\mathbf{\%})\end{array}$ & Rank \\
\hline $\mathbf{1}$ & Scarcity of skilled labour/ labour & 86 & II \\
\hline $\mathbf{2}$ & Non-availability of credit facilities in time & 63 & XII \\
\hline $\mathbf{3}$ & High price of seed, fertilizers and chemicals & 65 & XI \\
\hline $\mathbf{4}$ & Weather uncertainty & 78 & VIII \\
\hline $\mathbf{5}$ & Non-availability of compost & 75 & IX \\
\hline $\mathbf{6}$ & No trained youth in villages & 81 & VI \\
\hline $\mathbf{7}$ & High cost of organic inputs & 79 & VII \\
\hline $\mathbf{8}$ & Lack of technical information & 40 & XIV \\
\hline $\mathbf{9}$ & Lack of technical assistance & 56 & XIII \\
\hline $\mathbf{1 0}$ & Not getting proper information to climate change & 82 & V \\
\hline $\mathbf{1 1}$ & Agricultural land converted into non agricultural land & 89 & I \\
\hline $\mathbf{1 2}$ & High labour wages & 85 & III \\
\hline $\mathbf{1 3}$ & Non-availability of green fodder & 70 & X \\
\hline $\mathbf{1 4}$ & Unwillingness towards agriculture & 83 & IV \\
\hline
\end{tabular}

\section{References}

Balamurugan V. and Vetriselvan M., 2011. Constraints experienced by the marginal farmers in sugarcane cultivation. International J. of extn. edu. vol.7, 2011. pp- 21-23

Bhosale K. D., 2010. A study of Urbanization in Nagpur District Institute of Town planners. Indian J. 7-3, 88-95.

Davis K., 1965. The urbanization of human population. Scient. Am., 213. (No.3).

Davis K., HH Golden, 1954. Urbanization and the development of preindustrial area. $J$. of Economic development and cultural change, Vol. 3. pp- 6-26.

Gumsate, A. K., H.N. Patil and A.J. Nirban., 1993. Constraints in utilization of water under minor irrigation projects in Konkan. Maharashtra J. of Extn. Edu.12 pp. 372-375.

Jadhav R. M., 2015. Agriculture in Peri-Urban area around Mumbai. M. Sc. (Agri.) Thesis (Unpub.) Dr. BSSKV, Dapoli.

Karwande, M. D., (2009). Agriculture in peri urban and remote villages. M.Sc. (Agri.) Thesis (Unpub.) Dr. BSKKV, Dapoli.

Khurana C., 2010. Aslice of life in peri-urban India. The Financial express, 13 May. $h t t p ; / / w w w$.financial express.com

Kim M., 2012. Peri-urbanization and its impact on rural livehood in Mumbai Urban Fringe Report for $48^{\text {th }}$ ISOCARP congress 2012.

Tacoli Cecillia., 2003. The links between urban and rural development. Environment and Urbanization Vol. 15.

Tekale V. S., D. N. Bhalekar and J. I. Shaikh, 2013. Entrepreneurial behaviour of dairy farmers. International J. of Extn. Edu., Vol 9: 32-36.

\section{How to cite this article:}

Vrushali M. Yadav, Santosh S. Shende and Tekale V. S. 2019. Constraints Faced By Farmers in Agriculture Living In Peri-Urban Area of Nagpur. Int.J.Curr.Microbiol.App.Sci. 8(08): 2217-2219. doi: https://doi.org/10.20546/ijcmas.2019.808.256 